\title{
Character association and path analysis studies in pole type dolichos bean (Lablab Purpureus L.)
}

\begin{abstract}
Character association between yields and its component characters as well as path analysis of thirty seven pole type dolichos bean (Lablab purpureus L.) genotypes were studied during kharif 2013. The genotypic correlation coefficient was higher than phenotypic coefficient of variation for all most all characters under study. Number of pods per vine, pod length, pod width and average weight of 10 pods showed highly significant positive correlation with green pod yield per plot. Path analysis indicated that number of pods per in florescence, number of pods per vine, days to 50 per cent flowering and weight of 10 pods had positive direct effects on green pod yield. These traits could therefore be useful for yield improvement programme of pole type dolichos bean.
\end{abstract}

Volume 7 Issue 5 - 2017

\author{
BT Patil, CB Bachkar, BB Handal, KG Shinde \\ All India Coordinated Research Project on Vegetable Crops, \\ Mahatma Phule Krishi Vidyapeeth, India
}

\begin{abstract}
Correspondence: BT Patil,All India Coordinated Research Project on Vegetable Crops, Mahatma Phule Krishi Vidyapeeth, Rahuri 413722 (M.S.), India, Email btpatilveg@rediffmail.com
\end{abstract}

Received:June 17,2017 | Published:September 28, 2017

Keywords: dolichos bean, correlation, path analysis

\section{Introduction}

Dolichos bean is multipurpose crop grown for pulse, vegetable and forage. This crop is grown for its green pods, while dry seeds are used in various vegetable food preparations. In some part of country it is cultivated as forage crop for livestock. It is mostly confined to grown and cultivated on large extent in Karnataka, Tamil Nadu, Andra Pradesh, Maharashtra, Gujrath, Bihar, some part of Utter Pradesh and West Bengal. Both pole and bush type beans are cultivated for green pods in hills during summer and autumn season. These beans are grown as mono crop in commercialized peri- urban areas using staking for pole types beans. It is long duration crop grown either sole or mix crop with maize. It is major source of protein for households and also cash crop. Farmers regards bean as cash generating crop in hills and number of land races with various morphologies. It is a one of the most important leguminous crop widely grown in South and Ester India for its green pods and seeds. It is cultivated wide range of agroclimatic conditions from plains $300 \mathrm{~m}$ above sea level to high hills at $2500 \mathrm{~m}$ sea levels in different seasons. Beans are "meat of the poor" contribute essential protein to undernourished people living in hills. It also plays an important role in biological nitrogen fixation. It is self pollinated crop but often cross pollination (6-10\%) may occur due to insect. The pod yield, itself is not only important character but various component character also either jointly or singly important. Although dolichos bean being cultivated in India since long time, the crop remained underexploited and very little efforts seems to have been made for its improvement. Therefore, knowledge of genetic association of yield and various component characters are of economic worth in formulating and executing the breeding programme. Hence, the prime requirement is to have precise and clear cut information on the strength and direction of association of these traits with pod yield per plant and inter relation among themselves. The selection efficiency is improved by making judicious combinations of the characters. The degree of association between pod yield and its contributing characters can be estimated by correlation coefficient at genotypic and phenotypic levels. Correlation coefficient measures the association between any two characters; however, these may not give clear picture under complex situation. The knowledge of direct and indirect effects of yield contributing characters helps in the selection of high yielding genotypes. Therefore, present study was undertaken, employing 37 genotypes to analysis relationship between yield components, association among desired traits, extent and nature of direct and indirect effects of yield contributing characters in dolichos bean.

\section{Material and methods}

The study was conducted at All India Coordinated Research Project on Vegetable Crops, Department of Horticulture, Mahatma Phule Krishi Vidyapeety, Rahuri (M.S.) during the year 2013-14 (July 2013 to February 2014) with thirty seven widely divergent varieties of pole type dolichos bean collected from AICRP on Vegetable Crops, M.P.K.V. Rahuri. The experiment was laid out in Randomized Block Design with three replications having plot size of $5.0 \times 1.5 \mathrm{~m}$. with spacing of $1.0 \mathrm{~m}$. between plants within row and rows were $1.5 \mathrm{~m}$. apart. There were five plants in each replication and for each variety. The plants were trailed on trallies system made up of wodden balli and bamboo poles with iron wire stretched on both sides. The observations on days to first flowering, days to 50 per cent flowering, days to first harvest, length of inflorescence $(\mathrm{cm})$, number of flower inflorescence ${ }^{-1}$, number of pods inflorescence ${ }^{-1}$, number of pods vine ${ }^{-1}$, pod setting $(\%)$, pod length $(\mathrm{cm})$, pod width $(\mathrm{cm})$, number of grains pod ${ }^{-1}$, green pod yield plot $^{-1}$, and hectare ${ }^{-1}$ were recorded from all the 5 plants in each replication in each variety. Correlation coefficients among the characters at phenotypic and genotypic levels were analyzed following Hayes et al. ${ }^{1}$ and Singh et al. ${ }^{2}$ Path analysis at genotypic level was done according to Deway et al. ${ }^{3}$

\section{Results and discussion}

The correlation studies showed higher estimates of genotypic correlation coefficient than phenotypic correlation coefficient (Table 1) which indicated that this might be due to masking effect of environment in total expression of genotypes or a strong inherent association between various traits under study. Johnson, Srivastava, Nandapuri, Singh et al., ${ }^{4-7}$ also reported higher genotypic correlation than phenotypic one. In present study the green pod yield was positively and significantly correlated (Table 1) with number of pods per vine, pod length, pod width and average weight of 10 pods both 
at genotypic and phenotypic levels. Similar kinds of reports were reported by Kabir et al., ${ }^{8}$ Gnanesh et al..$^{9}$ In dolichos bean. Days to first flowering showed significant and positive correlation with days to 50 per cent flowering $\left(0.943^{*}\right.$ and $\left.0.934^{*}\right)$ and days to harvest $(0.921 * \& 0.888 *)$ at both genotypic and phenotypic levels. It showed on significant and positive correlation with pod setting (\%) 0.089 \& 0.034 , number of grains per pod $(0.150 \& 0.132)$ and average weight of 10 pods $(0.047 \& 0.046)$ at both genotypic and phenotypic levels. It also exhibited significant and negative association with length of inflorescence $(-0.225 \&-0.220)$ and green pod yield per plot $(-0.239$ $\&-0.221)$ at both genotypic as well as phenotypic levels.

However, it showed negative and non-significant correlation with number of flowers per inflorescence $(-0.146 \&-0.137)$, number of pods per inflorescence $(-0.123 \&-0.125)$ and pod width $(-0.013 \&-$ $0.015)$ at both genotypic as well as phenotypic levels. Similar findings were reported by Singh, Pandita et al. ${ }^{7,10}$ Days to 50 per cent flowering showed significant and positive correlation with days to first harvest $\left(0.978^{*} \& 0.948^{*}\right)$ at both genotypic and phenotypic levels. It showed non-significant and positive correlation with pod setting per cent (0.083 \& 0.009), pod length $(0.024 \& 0.040)$ and width $(0.037 \&$ $0.035)$, number of grains per pod $(0.189 \& 0.155)$ and average weight of 10 pods $(0.140 \& 0.137)$ at both genotypic as well as phenotypic levels.

Days to 50 per cent flowering had significant and negative association with the number of pods per vine $(-0.319 \&-0.279)$ and green pod yield per plot $(-0.269 \&-0.246)$ at genotypic as well as phenotypic levels. While, it showed negative and non-significant association with length of inflorescence (- $0.161 \&-0.158)$, number of flowers per inflorescence $(-0.130 \&-0.115)$ and number of pods per inflorescence $(-0.111 \&-0.115)$ at both genotypic as well as phenotypic levels. These results in agreement with those reported by Singh et al., ${ }^{11}$ in cowpea. The days to first harvest was not showed significantly positive correlation with none of character, however, it showed significant but negative association with number of pods per vine $(-0.299 * \&-0.262 *)$ and green pod yield per plot $(-0.312 * \&$ $\left.-0.283^{*}\right)$ at both genotypic as well as phenotypic levels.

It showed negative and non-significant association with length of inflorescence (- $0.149 \&-0.148)$, number of flowers per inflorescence $(-0.113 \&-0.092$ and number of pods per inflorescence $(-0.108 \&-0.110)$ at both genotypic and phenotypic levels. Length of inflorescence showed significant and positive correlation with number of flowers per inflorescence $\left(0.697 * \& 0.683^{*}\right)$, number of pods per inflorescence $(0.562 * \& 0.537 *)$ and number of pods per vine $(0.253 * \& 0.217 *)$ at both the levels. It showed non-significant and positive association with number of grains per pod $(0.193 \& 0.177)$ at both the levels. It had significantly positive association with pod setting percentage $\left(0.521^{*}\right)$ at genotypic level only. However, it had negative and significant association at phenotypic level $\left(-0.375^{*}\right)$ but pod width $\left(-0.313^{*} \&-0.307^{*}\right)$ at both genotypic as well phenotypic levels. These results are in accordance with Uddin et al. ${ }^{12}$ The number of flowers per inflorescence was significantly and positively correlated with number of pods per inflorescence $\left(0.873^{*} \& 0.819^{*}\right)$ and number of pods per vine $\left(0.229^{*} \& 0.217^{*}\right)$ at both genotypic as well as phenotypic levels. It recorded significantly and negative association with pod setting percentage $\left(-0.614^{*} \&-0.511^{*}\right)$, pod width $\left(-0.319^{*}\right.$ $\left.\&-0.313^{*}\right)$ and average weight of 10 pods $\left(-0.276 * \&-0.268^{*}\right)$ at both genotypic as well as phenotypic levels. It had negative and nonsignificant correlation with pod length $(-0.141 \&-0.130)$ and number of grains per pod (-0.036\&-0.035) at both genotypic and phenotypic levels. These results are in accordance with Ali et al. ${ }^{13}$

The number of pods per inflorescence was positively and significantly correlated with number of pods per vine $(0.309 * \& 0.263 *)$ at both genotypic and phenotypic levels. It showed significant but negative association with pod length $\left(-0.238^{*} \&-0.213 *\right)$, pod width $\left(-0.353^{*} \&-0.322^{*}\right)$ and average weight of 10 pods $\left(-0.360^{*}\right.$ $\&-0.341 *)$ at both genotypic as well as phenotypic levels, however, number of grains per pod $\left(-0.235^{*}\right)$ at genotypic level. It had positive and non-significant association with pod setting percentage $(0.030)$ at phenotypic level. These results are in accordance with Ali et al. ${ }^{13}$ Number of pods per vine showed positive and significant correlation with pod setting percentage $(20.94 *)$ at genotypic level and green pod yield per plot $\left(0.556^{*} \& 0.575^{*}\right)$ at both the genotypic as well as phenotypic levels. It showed negative and significant correlation with pod length $(-0.113 .79 * \&-0.109 .68 *$, pod width $(-0.14 .11$ * $\left.\&-0.13 .90^{*}\right)$, number of grains per pod $\left(-0.24 .89^{*} \&-0.22 .63^{*}\right)$ and average weight of 10 pods $(-0.213 .82 * \&-0.360 *)$ at both genotypic as well as phenotypic levels and pod setting percentage $(-2.34)$ at phenotypic level. Similar results were reported by Rai, Singh et al. ${ }^{14-16}$ in dolichos bean.

The pod setting percentage was positively and none significantly correlated with pod length $(0.114)$ at genotypic level and pod width $(0.061 \& 0.063)$ and green pod yield per plot $(0.043 \& 0.008)$ at both genotypic as well as phenotypic levels. It had negative and nonsignificant association with pod length $(-0.097)$ at phenotypic level however average weight of 10 pods $(-0.037 \& 0.036)$ at both genotypic and phenotypic levels. It showed negatively significant correlation with number of grains per pod $\left(-0.216^{*}\right)$ at phenotypic level. The pod length was positively and significantly correlated with pod width $(0.296 * \& 0.287 *)$, number of grains per pod $(0.490 * \& 0.449 *)$, average weight of 10 pods $\left(0.836^{*} \& 0.810^{*}\right)$ and green pod yield per plot $\left(0.469 * \& 0.455^{*}\right)$ at both genotypic as well as phenotypic levels. The pod width was positively and significantly correlated with average weight of 10 pods $(0.562 * \& 0.550 *)$ and green pod yield per plot $\left(0.336^{*} \& 0.325^{*}\right)$ at both genotypic as well as phenotypic levels. It showed non-significant but positive association with number of grains per pod $(0.059 \& 0.061)$ at both genotypic as well as phenotypic levels. These results are in agreement with those reported by Uddin et al. ${ }^{12}$ and Parmer et al. ${ }^{16}$ The number of grains per pod was significantly and positively correlated with average weight of 10 pods $\left(0.549 * \& 0.506^{*}\right)$ at both genotypic and phenotypic levels. It showed positive and non significant association with green pod yield per plot $(0.192 \& 0.191)$ at both genotypic and phenotypic levels. The average weight of 10 pods was positively and significantly correlated with green pod yield per plot $(0.342 * \& 0.324 *)$ at both genotypic and phenotypic levels. Similar results were reported by Upadhaya et al. ${ }^{17}$ The results of path analysis presented in Table 2 revealed that number of pods per inflorescence (1.320) exhibited maximum positive direct effects on yield per plot was observed due to number of pods per vine (0.977), followed by days to 50 per cent flowering $(0.762)$ and weight of 10 pods $(0.547)$. On the contrary, days to first harvest (-0.958), length of inflorescence (-0.236), number of flowers per inflorescence and pod setting percentage $(-0.856)$ exhibited negative direct effect on green pod yield. The number of flowers per inflorescence (1.15) shows highest positive indirect effect on green pod yield per plot via number of pods per inflorescence. While pod setting percentage (0.990) exhibited high positive and indirect effect by number of flowers per inflorescence on green pod yield per plot. 
The number of pods per inflorescence (-1.400) recorded high negative and indirect effect on green pod yield per plot via number of flowers per inflorescence. Similar finding was reported by Upadhgay et al. ${ }^{17}$ in dolichos bean. Pod width (0.515) and average weight of 10 pods $(0.445)$ recorded moderate positive indirect effect through number of flowers per inflorescence on green pod yield per plot. Whereas, moderate negative indirect were observed by average weight of 10 pods $(-0.496)$ via number of pods per vine on green pod yield per plot. These findings are inagrement with results reported by Venketashn et al. ${ }^{18}$ Lovely et al. ${ }^{19}$

The estimated residual effect was low (0.332), which indicated that about $75 \%$ of the variability in green pod yield was contributed by different plant characters studied. These residual effects towards green pod yield in present study might be due to other characters or environmental factors or sampling error Sengupth et al. ${ }^{20}$ On the basis of estimates of path analysis it is suggested that, number of pods per inflorescent, number of pods per vine and average weight of 10 pods are main contributors to green pod yield per plant and thus emphasis should be given in selecting plants with these characters for its yield improvement programme in dolichos bean.

\section{Conclusion}

The estimates of genotypic correlations in general were higher than phenotypic correlations showing little masking effects of environment on expression of characters under study. The pod yield exhibited significant and positive correlation with yield contributing characters such as average weight of 10 pods, number of pods vine ${ }^{1}$ and pod width at both genotypic and phenotypic levels. The path analysis study revealed that number of pods inflorescence $e^{-1}$ exhibited maximum direct effect on yield followed by number of pods vine1. It means that, as increased number of inflorescence and number of pods plant ${ }^{-1}$ increased yield plant ${ }^{-1}$ and hectare ${ }^{-1}$. Therefore these characters rewarding to give more focus while selection of genotypes for increasing yield of dolichos bean crop.

\section{Acknowledgements}

None.

\section{Conflict of interest}

The author declares no conflict of interest.

\section{References}

1. Hayes HK, Immer FR, Smith DC. Methods of plant breeding. 2nd ed. USA: McGraw Hill Book Co; 1995. p. 1-551.

2. Singh RK, Choudhary BD. Biometrical Methods in Quantitative Genetic Analysi. India: Kalyani Publisher; 1985. p. 1-22.

3. Dewey DR, Lu KH. A correlation with path coefficient analysis of components of crested wheat grass seed production. Agron J. 1959;47:314 318.
4. Johnson HW, Robinson HF, Comstock RE. Genotypic and phenotypic correlation in soyabean and their implication in selection. Agron J. $1955 ; 47: 314-318$.

5. Srivastava JP, Singh HN, Singh SP. Genetic studies on yield component in pea. Indian J agric Sci. 1973;42(11):1001-1004.

6. Nand puri BS, Singh S, Lal T. Studies on the genetic variability and correlation of some economic characters in sem. J Res. 1973;10:316-321.

7. Singh SP, Singh HN, Singh NP, et al. Genetic studies on yield components in field bean. Indian J Agril Sci. 1979;9(8):579-582.

8. Kabir J, Sen S. Correlation and path analysis in Lablab bean. Tropical Agriculture. 1989;66(3):281-283.

9. Gnanesh BN, Reddy SM, Raja Reddy K, et al. Genetic variability, character association and path analysis of pod yield and its component characters in field bean. GEOBIOS. 2006;33:163-168.

10. Pandita ML, Pandey SC, Sidhu AS, et al. Studies on genetic variability and correlation in Indian bean (Dolichos lablab). Harayana J Hort Sci. 1980;9(3-4):154-159.

11. Singh KB, Mehandirata PD. Genetic variability and correlation studies in cowpea. Indian J Genet. 1969;29(1):104-109.

12. Uddin S, Newaz MA. Genetic parameters and the association among flower and pod characteristics of hyacinth bean (Lablab purpureus L.). Legume Res. 1997;50:82-86

13. Ali F, Sikadar B, Roy AK, et al. Correlation and genetic variation of twenty different genotypes of Lablab bean, Lablab purpureus(L.) Sweet. Bangladesh J Bot. 2005;34 (2):125-128.

14. Rai N, Singh Pramod Kumar, Verma Ajay, et al. Multivariate characterization of Indian Bean [Lablab purpureus(L.) Sweet] Genotypes. J Plant Genet Resour. 2008;21(1):47-50.

15. Singh PK, Rai N, Lal H, et al. Correlation, path and cluster analysis in hyacinth bean. J Agric Tech. 2011;7(4):1117-1124.

16. Parmar AM, Singh AP, Dhillon NPS, et al. Genetic variability studies for morphological and yield traits in dolichos bean (Lablab purpureusL.). World J Agric Sci. 2013;9(1):24-28.

17. Upadhyay D, Mehta N. Biometrical studies in Dolichos bean for Chattisgarh Plains. Research J agric Sci. 2010;1(4):441-447.

18. Venkatesan M, Prakash M, Ganesan J. Genetic variability, heritability and genetic advance analysis in cowpea (Vigna unguiculata L.). Legume Res. 2003;26(2):155-156.

19. Lovely B, Radhadevi DS. Character association studies in Yard long bean (Vigna unguiculata var. Sesquipedalis). Indian J Plant Genet Resour. 2006;19(1):80-82.

20. Sengupta K, Kataria AS. Path coefficient analysis for some characters in soya bean. Indian J Genet. 1971;31:290-295. 